TAPROBANICA, ISSN 1800-427X. November, 2020. Vol. 09, No. 02: pp. 210-216.

(C) Research Center for Climate Change and Department of Biology, Faculty of Mathematics \& Natural Sciences, University of Indonesia, Depok 16424, INDONESIA.

http://www.taprobanica.org/

https://doi.org/10.47605/tapro.v9i2.233

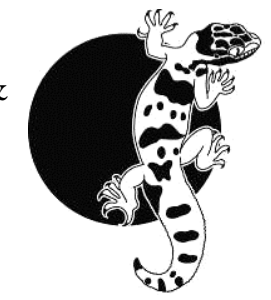

\title{
AN OVERVIEW OF THE HUMAN-ELEPHANT CONFLICT IN TISSAMAHARAMAYA, HAMBANTOTA DISTRICT, SRI LANKA
}

\author{
M.C.A. Galappaththi ${ }^{1,2}$, T.S.P. Fernando ${ }^{1}$ \& U.K.G.K. Padmalal ${ }^{1}$ \\ ${ }^{1}$ Department of Zoology, Faculty of Natural Sciences, The Open University of Sri Lanka, Nawala, Sri Lanka \\ ${ }^{2}$ Corresponding author.E-mail: mcagalappaththi@gmail.com
}

\begin{abstract}
Human-elephant conflict (HEC) is a major problem to Tissmaharama Divisional Secretariat (TDS) in Hambantota District, Sri Lanka. The current study was designed to identify and describe the patterns of HEC in TDS so that methods could be developed to minimise human and elephant deaths due to HEC. The data were collected through questionnaire surveys and internal data of the Department of Wildlife Conservation and the Meteorological Department of Sri Lanka. The results suggest that elephants feed on all cereals, fruits and vegetables available except citrus, pomegranate, sesame and bitter gourd. The majority of conflicts were caused by elephant groups of less than four individuals (94.3\%). Elephant raids occurred mainly during the night and especially escalate towards January and September. There were no correlations between rainfall and crop damage. Both human and elephant males were more likely to die from HEC than human and elephant females.
\end{abstract}

Key words: crop and property damage, human-elephant deaths, rain fall, wildlife management

\section{Introduction}

As a fascinating flagship and keystone species, and the largest living terrestrial animals, elephants have attracted human attention for millennia (Riddle et al. 2010). Human-elephant conflict (HEC) arises when elephants damage property and crops, and causes the deaths of both elephants and humans in Sri Lanka. Human-elephant conflict is a complex interaction between humans and elephants, and results in a detrimental impact on both species (Fernando et al. 2008). Loss of habitat from deforestation is one of the most serious issues elephants are facing worldwide, and illegal capture and internal trade has recently been identified as another major threat to Sri Lankan wild elephants (Prakash et al. 2020). In the early $19^{\text {th }}$ century Sri Lankan elephants (Elephas maximus maximus) were distributed throughout the island from the lowlands to the hills, but are now restricted to the lowlands. Sri Lanka's wild elephant population was 5,879 when last surveyed (DWC 2011). In 1990, 67.19\% of the total population lived in Protected Areas belonging to the Department of Wildlife Conservation (DWC), 29.78\% lived in areas belonging to the Forest Department (FD) and only $3.03 \%$ lived in and around forest patches 
adjacent to remote villages (Santiapillai \& Jackson 1990). Now, as the forest cover is increasingly depleted, more elephants are forced to live in forest patches adjacent to remote villages, which therefore suffer from HEC. Of Sri Lanka's $65,000 \mathrm{~km}^{2}$ land area $20 \%$ is covered by forest which belongs to National Parks. Sri Lanka contains $10 \%$ of the wild Asian elephant population but has only $2 \%$ the forest habitat available for this species (Perera 2009).

The human population of Sri Lanka is $20,359,439$ with a population density of 325 per $\mathrm{km}^{2}$ (CSD 2012). Accelerating human population growth is shifting the balance between nature and humans. Wild elephants, which are both browsers and grazers, are versatile herbivores, and have a daily food requirement of about $150 \mathrm{~kg}$ (McKay 1973, Vancuylenberg 1977). As non-ruminants they can consume a wider variety of food than other herbivorous mammals. In the wild they consume over 60 species of plants (McKay 1973). Grasslands are the favoured feeding habitat of elephants but they use more densely wooded habitats for movement, resting, breeding and shade (Alahakoon et al. 2017). As such they depend on forest ecotones (Fernando 2015). Elephants are active during the day time and feed in open areas while they are in protected areas but when they are outside protected areas they remain in scrub refuges during the day. They feed on a variety of food items ranging from grains, cereals and other crops at night (Wikramanayaka et al. 2004, Samansiri \& Weerakoon 2007). Thus, elephants tend to come out of forest core areas where food resources are sparse and move towards the edges where they can find good feeding grounds.

Crop raiding by wild elephants is influenced by factors such as elephant density in the wild, proximity to villages, rainfall, shade availability, cattle grazing, forest fires, wood cutting, water availability and available forage plant species (Daniel 1995). During the dry season, elephants enter the chena (=shifting cultivation) and feed on plant material left over by farmers and also the sprouting stumps of Limonia sp. (Family Rutaceae) and Bouhinia sp. (Family Fabaceae). During the wet season they move back to the protected areas when fields are cultivated by farmers (Wikramanayaka et al. 2004). Elephants living in Bangladesh mostly prefer rice paddy, grass, bamboo, jackfruit, mango and banana. Non-preferred foods are chilli, citrus, bitter gourd, okra, taro and teasel gourd (Wahed et al.
2016). Crops avoided by elephants in Sri Lanka include citrus, cashew and neem (Samansiri \& Weerakoon 2007, Santiapillai et al. 2010).

HEC has been well studied in other parts of Sri Lanka, but poorly studied in Tissamaharamaya. Hambantota District, which is rapidly industrializing and becoming urbanized. Newly constructed Mattala Rajapaksa International Airport, Magampura Mahinda Rajapaksa Port and new housing projects will likely increase HEC in Tissamaharamaya. More research is needed to implement effective mitigation methods against HEC. Therefore, the overall objective of this study is to identify the patterns of HEC in this region.

\section{Material and methods}

Study location: This study was conducted in Tissmaharama Divisional Secretariat (TDS) which belongs to Hambantota District in Southern Province, Sri Lanka. It is surrounded by four National Parks (NPs): Yala NP, Bundala NP, Lunugamwehera NP and Udawalawa NP. It also contains sanctuaries such as Nimalawa, Wilmanna, and Tissamaharamaya and other forest reserves. Hambantota District $\left(6^{\circ} 15^{\prime} \mathrm{N}\right.$ $81^{\circ} 10^{\prime} \mathrm{E}$ ) covers $2,609 \mathrm{~km}^{2}, 2,496 \mathrm{~km}^{2}$ of land and $113 \mathrm{~km}^{2}$ of water. Tissmaharama is the largest Divisional Secretariat in Hambantota District. The climate is dry and dominated by scrub and semi evergreen dry monsoon forest. Tissmaharama DS consists of lagoons, water tanks, rocks and southern beach riparian habitat (Figs. 1, 2). Both primary and secondary data were collected to complete the research objectives. The primary data were collected through direct observations and questionnaires. The secondary data were already available from DWC and Meteorological Department (MD).

Questionnaire survey and Secondary Data: The questionnaire survey was carried out from May to December 2017 in TDS to gather the primary data. The questions covered incidents that occurred from October 2016 to September 2017. Questionnaires were filled by cluster sampling method by dividing the TDS to 100 grids. The size of each grid was 4 square $\mathrm{km}$. Some grids on the periphery included areas beyond the TDS boundary. In such instances only the grid area within the TDS was considered. One random point within every grid was selected and the questionnaire was given to one person living closest to the point, and the latitude and longitude were recorded with GPS. 
The questionnaire was used to collect qualitative and quantitative data, such as number of incidents of crop damage, house damage, and water tank damage and also the crop types consumed and house types damaged. Secondary data were collected from DWC and MD. Data on elephant deaths and human deaths due to HEC in Hambantota District were available from January 2013 from DWC. Rainfall data for Hambantota District from October 2016 to September 2017 was available from MD. Data were analysed by SPSS software and Microsoft Excel software.
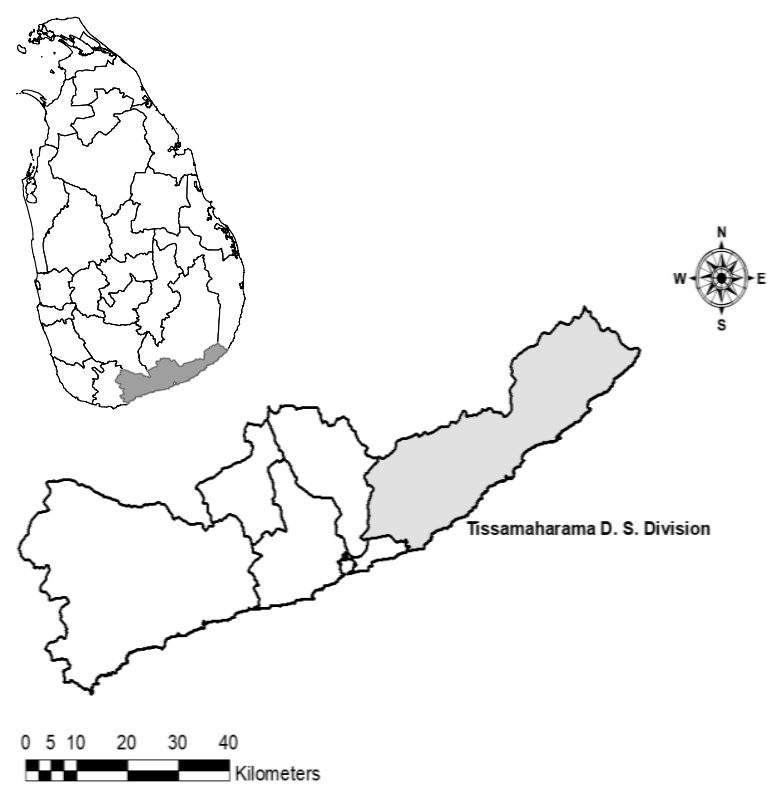

Figure 1. Map of Sri Lanka with Hambantota District shaded (above) and Hambantota District with Tissamaharama D.S. division shaded (below)

\section{Results}

Patterns of Crop and Property Damage: Crop raiding was the most common form of damage in TDS. During the study period 135 crop damage incidents were recorded. Elephants had consumed 40 plant varieties grown by humans. Vegetables were the most highly consumed crop type at $38.53 \%$ (Fig. 2).

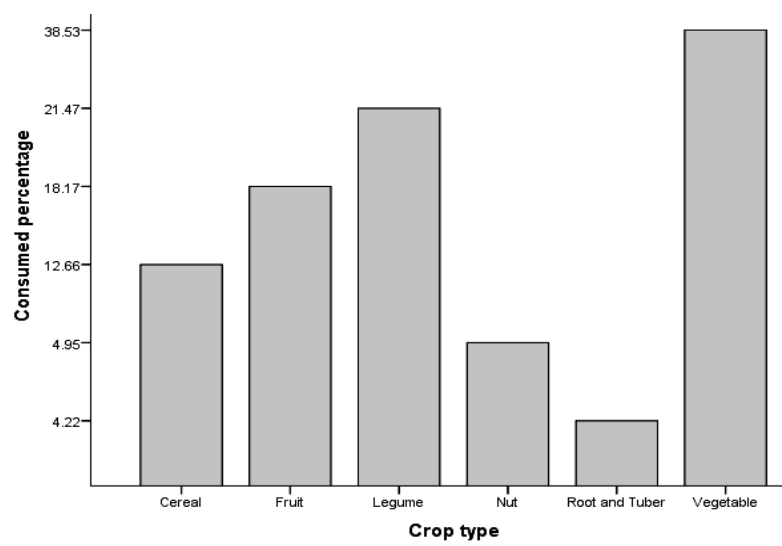

Figure 2. Percentages of crop types consumed by elephants in Tissamaharama D.S. division from October 2016 to September 2017

Long bean, Vigna unguiculata, was the most consumed crop plant within the study period $(n=42)$. Water melon, Citrullus lanatus ( $n=36)$; pumpkin, Cucurbita moschata $(n=29)$; and corn, Zea mays $(n=30)$ were other commonly consumed vegetables. Citrus (Citrus sp.) $(n=32)$; sesame, Sesamum indicum $(n=19)$; bitter gourd, Momordica charantia $(n=20)$; pineapple, Ananas comosus $(n=2)$; and abarella, Spondias dulcis $(n=1)$ were not consumed by elephants (Fig. 3).

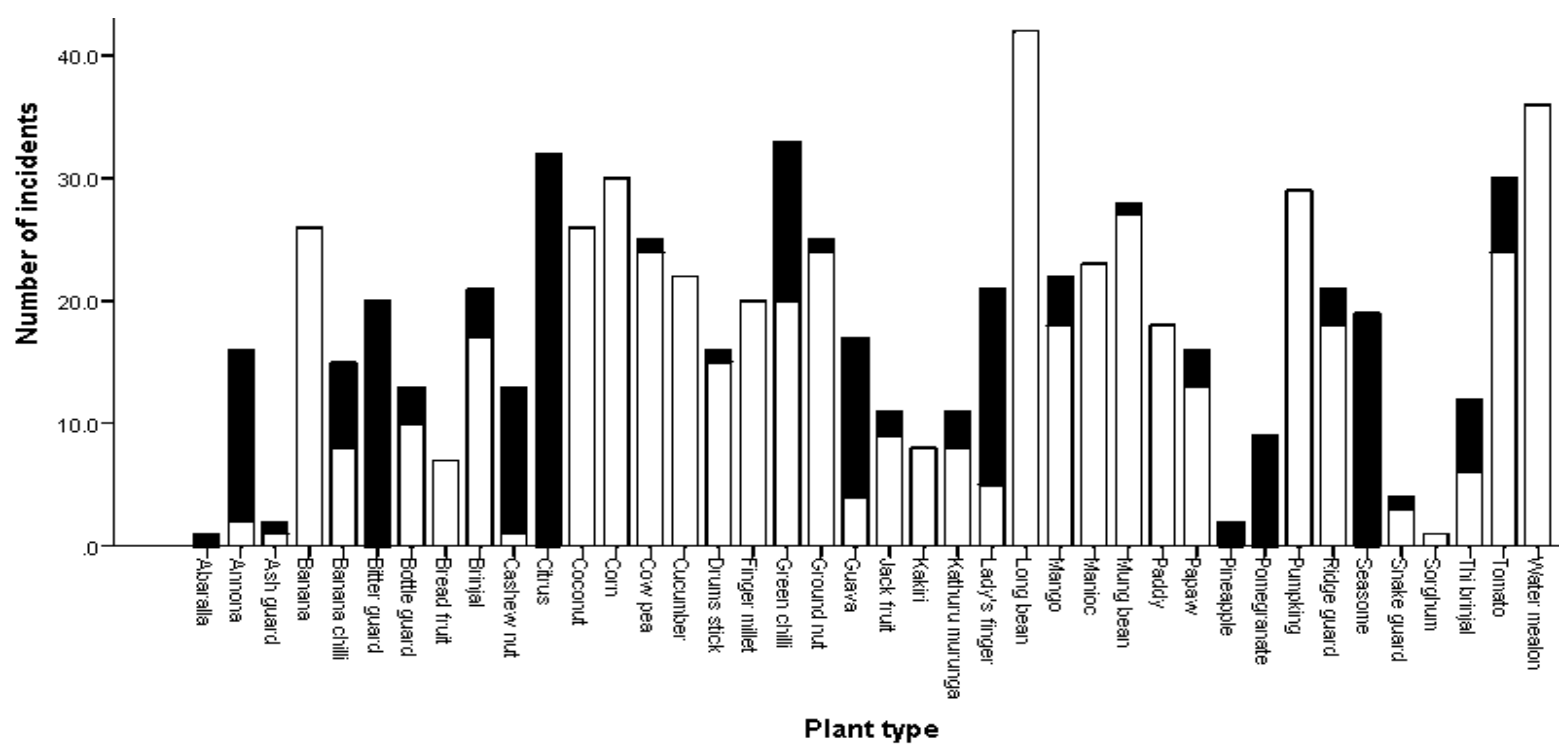

Figure 3. Consumption of crop plant varieties in Tissamaharama D.S. from October 2016 to September 2017; not consumed (black), consumed (white) 
$52.6 \%$ of houses damaged by elephants were mostly temporary structures, while $47.4 \%$ were permanent houses. This difference was not significant (Chi-square goodness of fit test, $\left.n=19, \chi^{2}=0.053, p=0.819\right)$. Of the destroyed permanent houses, $66.7 \%$ were made of concrete and $33.3 \%$ were made of clay. There was no significant difference between the number of cases: concrete and clay houses destroyed by elephants $\left(n=9, \quad \chi^{2}=1.000\right.$, $p=0.317$ ).

Further, there was no significant correlation with rainfall and the crop raiding by elephants $[\mathrm{r}=-0.054, \quad p=0.867]$. There was also no significant correlation between rainfall and the reported total damage incidents to crops, houses and water tanks $[\mathrm{r}=-0.073, P=0.822]$. The number of elephants participating in each incident of crop and property damage was fewer than five. Single elephants caused $57.2 \%$ of damage and $94.3 \%$ were caused by fewer than four elephants $(\mathrm{M}=1$; range $1-4 ; n=159)$ (Fig. 4).

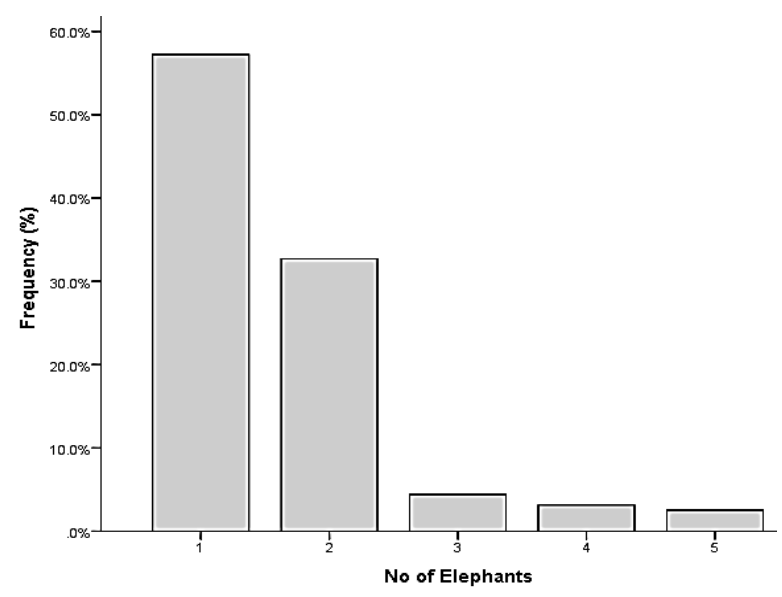

Figure 4. Frequency of elephants participating in crop and property damage

Most elephant attack incidents (99.4\%) were recorded at night, between 19:00 $\mathrm{h}$ and 05:00 h $(n=159)$. Only one incident was recorded during the day at 15:00 $\mathrm{h}$ (Fig. 5).

The highest number of damage incidents were in September $(n=38)$. October $(n=1)$ and November $(n=1)$ were the months with least conflict. The highest house damage incidents were during February $(n=4)$ and September $(n=4)$. Water tanks of the houses and water bowsers were damaged by the elephants in May $(n=1)$, July $(n=1)$, August $(n=2)$, and September $(n=1)$ (Fig. 6).

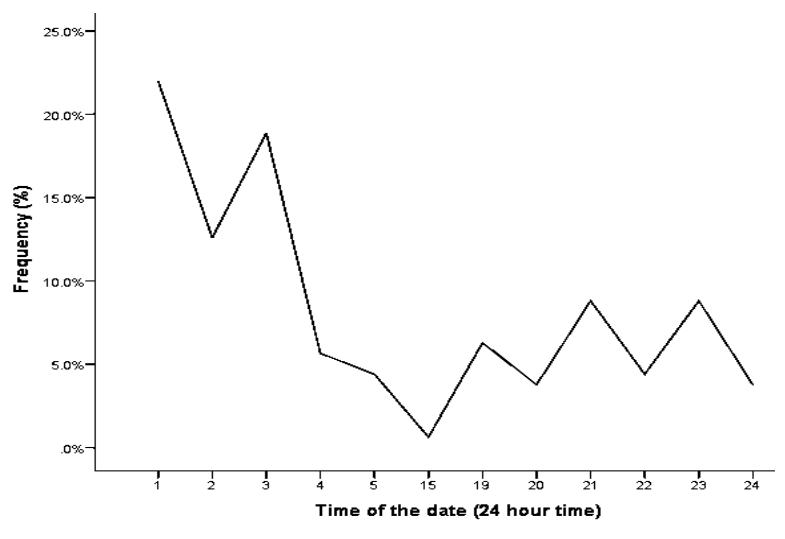

Figure 5. The frequency of elephant attacks over the course of a day

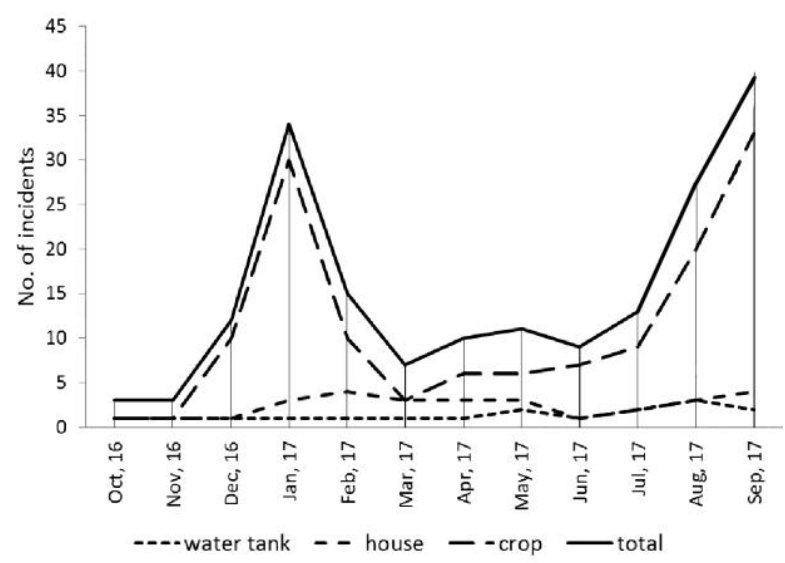

Figure 6. The number of water tank, house, crop, and total damage incidents each month

Elephant and human deaths: The percentages of male and female elephants killed while damaging crops or property or attacking humans in Hambantota District were $68.2 \%$ and $31.8 \%$, respectively, although this difference was not significant $\left(n=22, \chi^{2}=2.909, p=0.088\right)$. The mean age of the dead elephants was 18 years (Fig. 7). Elephant deaths were due to electrical fences (52\%), gun shots (29\%), and ingestion of poison (9\%) (Fig. 8). In Hambantota District $83.3 \%$ of human deaths were males and $16.7 \%$ were females. This difference was significant $\left(n=18, \quad \chi^{2}=8.000\right.$, $p=0.005)$. The mean age of the humans killed in HEC was 59 years (Fig. 9).

\section{Discussion}

This study was focused on the patterns of crop raiding, human deaths and elephant deaths. Results showed intense HEC in the study area, with numerous deaths of both humans and elephants. The most commonly consumed crop types were vegetables. Long bean, water melon, 
corn, and pumpkin were the most commonly consumed plants. Citrus, sesame, bitter gourd, pomegranate and pineapple were not consumed. Okra, Abelmoschus esculentus; cashew nut, and custard-apple (Annona) plants were least commonly consumed even though they are cultivated. Cucumber and ash gourd, Benincasa hispida were mostly consumed by elephants during the Yala farming season, from mid-May until early-October. Although crop types were broadly classified and identified as consumed or not, actual food preferences of elephants cannot be determined by a questionnaire only, because crop selection by humans is highly variable depending on water availability, economic factors and other environmental factors.

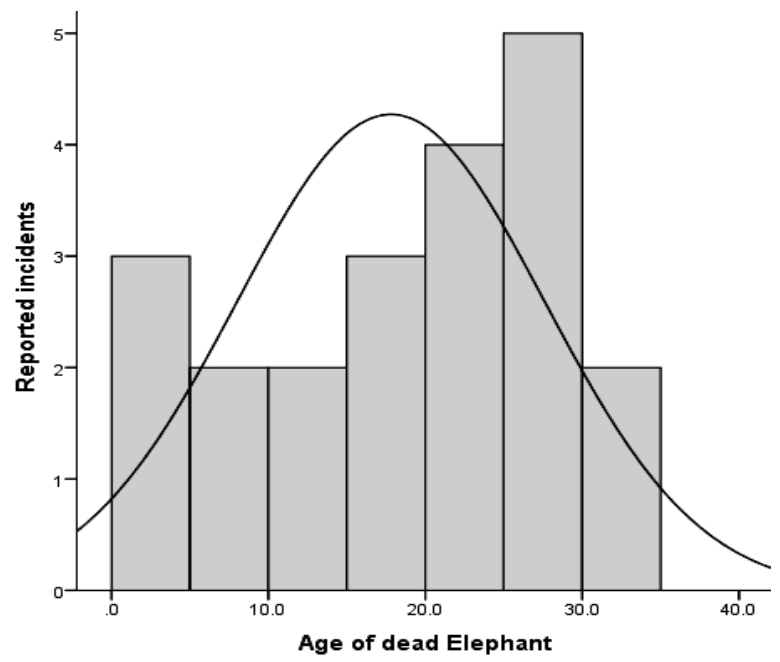

Figure 7. Reported incidents of elephant deaths against the age in Hambantota district (2013-2017); mean \pm sd $=17.81 \pm 9.81(n=21)$

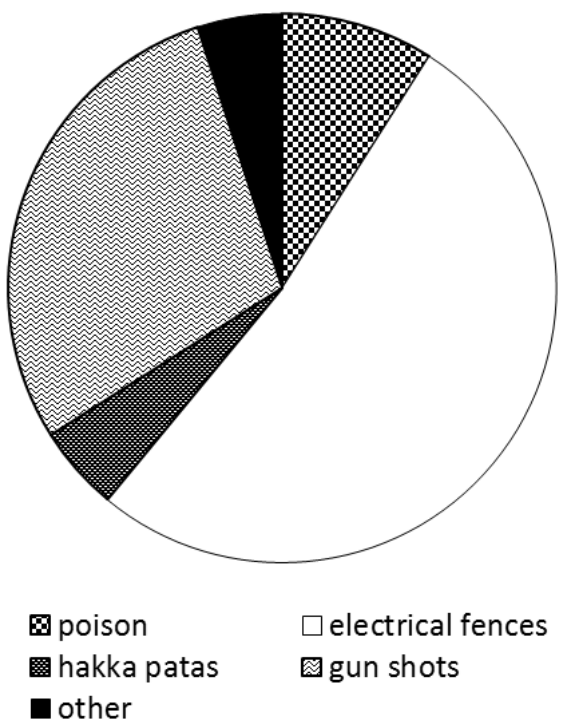

Figure 8. Causes of mortality in wild elephants in Hambantota District from 2013 to 2017

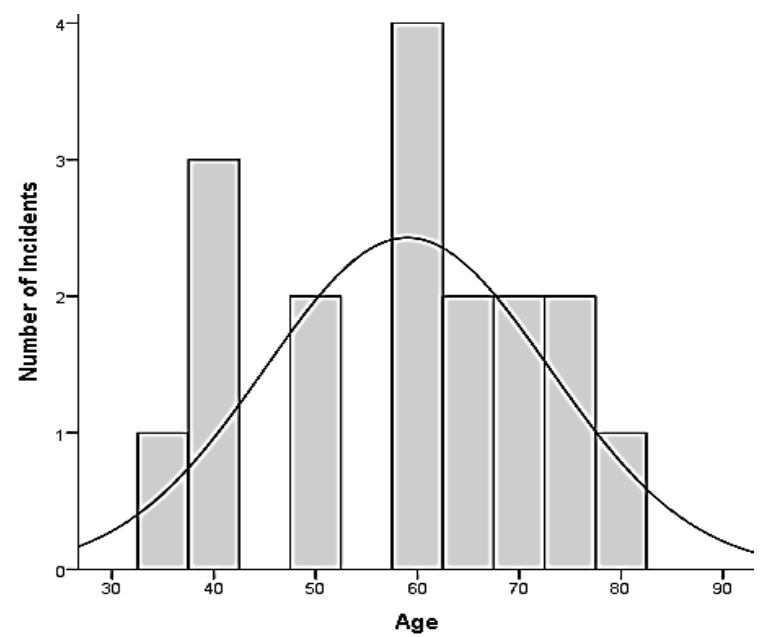

Figure 9: Reported incidents of human deaths (due to HEC) against the age in Hambantota district (2013-2017); mean \pm sd $=59.0 \pm 13.9(n=17)$

No significant correlations were found between rainfall and crop raiding or total damage during the study period. Recorded crop and property damage incidents decreased with increased numbers of elephants participating. Most crop and property damage occurred between 19:00 h to 05:00 h. The mean age of elephants killed was 18 years and there was no statistically significant difference between male and female elephants causing HEC. Most elephant deaths were caused by electrical fences which were not maintained up to the proper standard, such as the use of direct current for the fences. More human males were killed due to HEC than females and the mean age was 59 years.

Bull elephants have high food consumption because of their large body size relative to females, and this may be one reason that most damage is caused by males, besides that the males are naturally more aggressive. Additionally female matriarchs may tend to remain in cover and avoid HEC to protect their young. According to earlier research the monthly distribution of HEC incidents was strongly negatively correlated with rainfall (Campos-Arceiz et al. 2009), but based on the findings of this research we hypothesise that this pattern is interrupted by the chena farming system. January, when the second highest crop damage incidents were recorded, is the start of the harvesting season for chena farmers. Also in January 2017, there was high rainfall. Rainfall decreased highly and diminished into February. Because of that, most farmers had left their farmlands by then, and HEC incidents decreased. 
During the study period from November 2016 to January 2017, Tissamaharamaya region and adjacent National Parks had comparatively high rainfall. Because of this high rainfall, plants in the forests grew well. Also, there were abundant natural water sources inside the park. Therefore, the elephants mostly remained in the national parks and forested areas. Elephants are seasonal crop raiders; they came to the chena farmlands in the autumn and damaged the crops of farmers. Numbers of incidents then decreased because the chena farmers start to clear the lands during the October. In November also there was less crop damage because the crops in chena cultivation were immature and elephants do not like to eat immature plants. Since chena lands are normally situated in between the National Park or sanctuaries and the villages, the chena fields with immature crops interrupted the elephant's path to the villages.

Elephant herds are matriarchal, led by the oldest female (De Silva \& De Silva 2007). More than three elephants being involved in HEC incidents were rare. Even when they come as large herds, when they enter the chena farmlands they separate into family groups. When family groups enter the fields, they bring their cubs and make considerable noise compared to the single elephant. Then farmers can easily hear and respond to the elephant attack. Since most of incidents were caused by single elephants, and most of them were bulls, most house damage was also done by single elephants. Bulls are also aggressive when the farmers try to chase them away.

According to previous research (Santiapillai et al. 2010), as in this study, elephants entered the agricultural lands mostly at night. Numbers of incidents were highest at 19:00-04:00 $\mathrm{h}$ and least in 09:00-16:00 h. Of the elephants entering farming areas, $22 \%$ spent less than an hour, $19 \%$ spent 1-2 hrs, and 52\% spent over $2 \mathrm{hrs}$ (Santiapillai et al. 2010). The findings of our research are also very close to this. We recorded the highest incidents between 19:00 $\mathrm{h}$ and 05:00 $\mathrm{h}$ and the least in daytime. At day time they rarely come to the farmlands: they stay in the forest patches nearby and wait for darkness to raid the crops. Elephants mature after about 13 years of age (Meyer 2015), and the majority of elephants killed in Hambantota District because of HEC were 15-29 years old. During the mating season, or the musth season, they are aggressive. Normally, villagers kill aggressive elephants with gunshots. As a result, the population of animals 13 or more years old is decreasing. Among all the elephants killed in Hambantota District, most died before 35 years of age because of electrical fences, gunshots and hakka-patas (a kind of local explosive), poison, and cables. More research is needed on the life span of elephants in the wild that are involved in HEC, and those that are not.

More human males than female were killed during HEC encounters. That may be because most HEC incidents were recorded at night. In Sri Lankan villages girls and women do not normally walk at night. Mostly the men go to protect the farms. Most humans killed in HEC were between 60-69 years of age because they work until that age. Consequently, it is these frail elders who usually go out to protect their homes and farms, and become casualties. Villagers 30 to 39 years of age again were less frequently killed. Young villagers go to the jobs in city after their studies. Most people in the communities of the area are farmers. They do paddy cultivation, home garden cultivation and chena cultivation. They use water for agriculture from large reservoirs, small tanks, rainfall and ground water. Chena cultivation is done mainly in the monsoon season from end of September to March. The duration depends on the rainfall. In chena cultivation, they use land that belongs to DWC or FD. When the monsoon comes, they clear the government lands and cultivate seasonal crops such as corn, finger millet, sesame, long bean, water melon, cucumber, green chilli, okra and lots of crops. On their private lands, they grow banana, papaw, mango, lemon, pomegranate and jack fruit as long term crops. This farming system, with elephants living in the surrounding national parks and other forest patches, leads to a high level of conflicts between humans and elephants.

Many developmental projects are proposed or being built in this area, which is one of the top tourist resorts in Sri Lanka. Several factors affecting the HEC were identified in this study. Authorties can use these results to plan developments and design public awareness programs. Minimizing forest fragmentation, creating elephant corridors between fragments and making more water sources available for elephants will help to minimize the HEC.

\section{Acknowledgments}

We thank Gajaba Ellepola, Prince Manamperi, Gihan Dahanayaka, and Thusitha Jayasuriya at the Department of Zoology (Open University of 
Sri Lanka) for the support. Also we thank W.A. Dharmakeerthi (veterinary surgeon, DWC), the staff at the Metrological Department of Sri Lanka, the Department of Wildlife Conservation and, the Division Secretariat Tissamaharamaya for the support. The villagers of Tissamaharamaya are acknowledged for the support during the field works. Finally we thank Lee Harding (Canada), Chris Margules (James Cook University, Australia) and Philip Bowles (IUCN) for reviewing the manuscript.

\section{Literature cited}

Alahakoon, A.M.D.B., E.M.A.B. Pushpakumara, G. Ellepola, and K.B Ranawana (2017). Food and feeding patterns of Asian elephants in Udawalawe National Park, Sri Lanka. Gajah, 46: 4-13.

Campos-Arceiz, A., S. Takatsuki, S.K.K. Ekanayaka, and T. Hasegawa (2009). The human-elephant conflict in southeastern Sri Lanka: type of damage, seasonal patterns and sexual differences in the raiding behavior of elephants. Gajah, 31: 5-14.

CSD (2012). Census of Population and Housing 2012: provisional information based on 5\% sample. Department of Census and Statistics, Ministry of Finance and Planning, Sri Lanka, Colombo: $159 \mathrm{pp}$.

Daniel, J.C. (1995). Ecology of the Asian Elephant: Final Report (1987-1992) India. Ministry of Environment and Forests, US Fish \& Wildlife Service and Bombay Natural History Society, Bombay; 272pp.

DWC (2011). Performance Report. Department of Wildlife Conservation, Sri Lanka, Colombo: 74pp.

De Silva, M. and P.K. De Silva (2007). The Sri Lankan Elephant: Its Evolution, Ecology and Conservation, WHT, Colombo: 278pp.

Fernando, P. (2015). Managing elephants in Sri Lanka: where we are and where we need to be. Ceylon Journal of Science (Biological Sciences), 44 (1) : 1-11.

Fernando, P., M.A. Kumar, A.C. Williams, E. Wikramanayake, T. Aziz et al. (2008). Review of Human-Elephant Conflict Mitigation Measures Practiced in South Asia (AREAS technical support document submitted to World Bank) WWF Gland: 45pp.

Mckay, G.M. (1973). Behavior and Ecology of the Asiatic Elephant in Southeastern Ceylon, Smithsonian Contributions to Zoology, No. 125. Smithsonian Institution Press, Washington DC: 113pp.
Meyer, A. (2015). Elephants Forever <www.elephantsforever.co.za> Accessed on 11 May 2017.

Perera, B. (2009). The human-elephant conflict: a review of current status and mitigation methods. Gajah, 30: 41-52.

Prakash, T.G.S.L, W.A.A.D.U. Indrajith, A.M.C.P. Aththanayaka, S. Karunarathna, M. Botejue et al. (2020). Illegal capture and internal trade of wild Asian elephants (Elephas maximus) in Sri Lanka. Nature Conservation, 42: 51-69.

Riddle, H.S., B.A. Schulte, A.A. Desai, and L. van der Meer (2010). Elephants - a conservation overview. Journal of Threatened Taxa, 2 (1): 653-651.

Samansiri, K.A.P. and D.K. Weerakoon (2007). Feeding behavior of Asian elephants in the northwestern region of Sri Lanka. Gajah, 27: 27-34.

Santiapillai, C. and P. Jackson (1990). The Asian Elephant: An Action Plan for Its Conservation. IUCN, Gland: 79pp.

Santiapillai, C., S. Wijeyamohan, G. Bandara, R. Athurupana, N. Dissanayake et al. (2010). An assessment of the human-elephant conflict in Sri Lanka. Ceylon Journal of Science (Biological Sciences), 39 (1): 21-33.

Vancuylenberg, B.W.B. (1977). Feeding behavior of the asiatic elephant in South-East Sri Lanka in relation to conservation. Biological Conservation, 12 (1): 33-54.

Wahed, M.A., M.R. Ullah, and H.M. Irfanulla (2016). Human-Elephant Conflict Mitigation Measures: Lessons from Bangladesh. IUCN, Bangladesh Country Office, Dhaka, Bangladesh: 30pp

Wikramanayaka, E.D., H.S. Hathurusinghe, H.K. Janaka, L.K. Jayasinghe, P. Fernando et al. (2004). The human-elephant conflict in Srilanka: lessons for mitigation, management, and conservation from traditional land use patterns. In: Jayewardene, J. (ed.). Endangered Elephants Past, Present, and Future. Proceedings of the symposium for human elephant relationships and conflicts, Sri Lanka (September, 2003). Biodiversity and Elephant Conservation Trust, Colombo: 164-169.

Published date: 28 November 2020 
- blank page -

TAPROBANICA VOL. 09: NO. 02 